\title{
Operationalization and application of "early warning signs" to screen nanomaterials for harmful properties
}

Hansen, Steffen Foss; Nielsen, K. N.; Knudsen, N.; Grieger, Khara Deanne; Baun, Anders

Publication date:

2013

Document Version

Publisher's PDF, also known as Version of record

Link back to DTU Orbit

Citation (APA):

Hansen, S. F., Nielsen, K. N., Knudsen, N., Grieger, K. D., \& Baun, A. (2013). Operationalization and application of "early warning signs" to screen nanomaterials for harmful properties. Abstract from SETAC Europe 23rd Annual Meeting, Glasgow, United Kingdom.

\section{General rights}

Copyright and moral rights for the publications made accessible in the public portal are retained by the authors and/or other copyright owners and it is a condition of accessing publications that users recognise and abide by the legal requirements associated with these rights.

- Users may download and print one copy of any publication from the public portal for the purpose of private study or research.

- You may not further distribute the material or use it for any profit-making activity or commercial gain

- You may freely distribute the URL identifying the publication in the public portal 
WE096 Operationalization and application of "early warning signs" to screen nanomaterials for harmful properties.F. Foss Hansen,

Technical University of Denmark / DTU Environment; K.N. Nielsen, GenØk, Centre for Biosafety; N. Knudsen, LEO Pharma A/S; K.D.

Grieger, Technical University of Denmark / Department of Management Engineering; A. Baun, Technical University of Denmark / Department of Environmental Engineering. In 2001 the European Environment Agency (EEA) published a report that analyzed 14 cases of technological developments that later on turned out to have negative side-effects and they identified 12 "late lessons" for current and future policy-makers to have in mind when initiating new technological endeavors. This paper explores how the first lesson - "Acknowledge and respond to ignorance, uncertainty and risk in technology appraisal" could be applied to screen nanomaterials. In cases of ignorance, uncertainty and risk, the EEA recommends paying particular attention to important warning signs such as novelty, persistency, whether materials are readily dispersed in the environment, whether they bioaccumulate or lead to potentially irreversible action. Through an analysis of these criteria using five well-known nanomaterials (titanium dioxide, carbon nanotubes, liposomes, poly(lactic-co-glycolic acid) and nanoscale zerovalent iron, and carbon nanotubes), it was found that only nanoTiO2 fulfills all the five criteria. Dependent on the length of the nanotubes, carbon nanotubes fulfills 3 or 4 criteria whereas liposomes, poly(lacticco-glycolic acid), nanoscale zero-valent iron fulfills only one criteria. Finally, we discuss how these warning signs can be used by different stakeholders such as nanomaterial researchers and developers, companies and regulators to design benign nanomaterials, communicate what is known about nano-risks and decide on whether to implement precautionary regulatory measures. In 